\title{
Pengembangan instrumen tes dribbling pada permainan futsal menggunakan teknologi mikrokontroler arduino
}

\author{
Randy Febri Tauba*, Bafirman HB \\ ${ }^{1}$ Fakultas Ilmu Keolahragaan, Universitas Negeri Padang, Sumatera Barat \\ Jl. Prof. Hamka, Air Tawar, Padang, 25131 \\ * Coresponding Author. E-mail: rtauba@gmail.com
}

Received: June 28, 2021; Accepted: September 7, 2021 ; Published: September 25, 2021

\begin{abstract}
Abstrak: Penelitian ini bertujuan untuk membuat prototipe instrumen tes dribbling futsal menggunakan teknologi mikrokontroler arduino yang terhubung dengan aplikasi android. Penelitian ini merupakan penelitian dan pengembangan (Research and Development). Subjek penelitian adalah Pemain Futsal SMA N 1, 2 dan 9 Sijunjung, Kecamatan Sijunjung, Kabupaten Sijunjung, Sumatera Barat. Untuk Validasi alat oleh tiga orang ahli yaitu ahli Evaluasi dan Tes Pengukuran, Ahli Futsal, dan Ahli IT. Pengembangan instrumen tes dribbling futsal ini dilakukan dengan uji kelompok kecil dengan sampel 15 orang putra dan uji kelompok besar dengan sampel 45 orang putra. Metode yang digunakan adalah metode validitas ahli dengan penilaian menggunakan instrumen angket dan metode test dan retest untuk uji reliabilitas alat yang dianalisis dengan menggunakan rumus $r$ korelasional. Hasil dari penelitian ini Hasil dari penelitian ini didapatkan nilai validitas sebesar 91,33\%, kategori "Sangat Baik/layak" dan uji reliabilitas kelompok kecil sebesar 0.986, dengan kategori "Tinggi" dan kelompok besar sebesar 0.947, dengan kategori "Tinggi". Kemudian didapatkan nilai praktisitas sebesar $94 \%$ dan nilai efektivitas sebesar $90 \%$, maka disimpulkan bahwa instrumen tes dribbling futsal menggunakan teknologi mikrokontroler arduino efektif digunakan sebagai alat ukur untuk mengukur kecepatan dribbling futsal.
\end{abstract}

Kata Kunci: instrumen, dribbling, futsal

\section{Development of dribbling test instruments in futsal games using arduino microcontroller technology}

\begin{abstract}
This study aims to make a prototype of the futsal dribbling test instrument using Arduino microcontroller technology that is connected to an Android application. This research is a research and development (Research and Development). The research subjects were Futsal Players SMA N 1, 2 and 9 Sijunjung, Sijunjung District, Sijunjung Regency, West Sumatra. For tool validation by three experts, namely Evaluation and Measurement Tests, Futsal Experts, and IT Experts. The development of the futsal dribbling test instrument was carried out with a small group test with a sample of 15 men and a large group test with a sample of 45 men. The method used is the expert validity method with an assessment using a questionnaire instrument and the test and retest method to test the reliability of the tools analyzed using the correlation $r$ formula. The results of this study obtained a validity value of $91.33 \%$, the category "Very Good / feasible" and the small group reliability test was 0.986, with the "High" category and the large group was 0.947, with the "High" category. Then obtained a practical value of $94 \%$ and an effectiveness value of $90 \%$. Thus, it can be concluded that the futsal dribbling test instrument using arduino microcontroller technology is good for use as a measuring tool to measure the speed of futsal dribbling.
\end{abstract}

Keywords: Instrument; Dribbling; Futsal

How to Cite: Tauba, R.F \& Bafirman, B. (2021). Pengembangan instrumen tes dribbling pada permainan futsal menggunakan teknologi mikrokontroler arduino. Jurnal Keolahragaan. 9 (2), 256-267. doi: https://doi.org/10.21831/jk.v9i2.41845 
Jurnal Keolahragaan 9 (2), 2021 - 257

Randy Febri Tauba, Bafirman HB

\section{PENDAHULUAN}

Salah satu cabang olahraga yang berkembang dengan pesat adalah futsal. Menurut Tenang (2008:15), "Futsal adalah singkatan dari futbol dan sala atau futebol dan salon". Permainan ini membentuk pemain dengan tujuan bahwa ia selalu siap untuk mendapatkan dan mengoper bola dengan cepat di bawah tekanan dari pemain lawan. Permainan futsal menuntut teknik penguasaan bola tinggi, kerjasama antar pemain, dan kekompakan tim. Castagna et al., (2009) mengungkapkan bahwasanya futsal adalah olahraga yang membutuhkan tuntutan fisik, teknik, dan taktik yang tinggi pada setiap pemainnya. Rahmani (2014: 157) menyatakan "Futsal merupakan olahraga yang dimainkan oleh dua tim yang berlawanan". Selain itu, futsal umumnya dimainkan di lapangan indoor atau ruangan. Seperti yang dikemukakan oleh (Ishak et al., 2008), "Futsal merupakan permainan cepat dengan waktu relatif pendek, serta memiliki ruang gerak yang sempit". Permainan futsal mempunyai karakteristik yang cepat dimana semua pemain aktif berpartisipasi secara merata dan kapan saja bisa main walaupun dalam keadaan fase bertahan atau menyerang.

Futsal adalah olahraga anaerobik, Metabolisme energi secara anaerobik terdiri dari dua sistem yaitu sistem phosphocreatin ( $\mathrm{PCr}$ ) dan sistem glikolisis anaerobatau dikenal dengan sistem pembentuk laktat sehingga dapat dihasilkan langsung untuk memenuhi kebutuhan energi pada saat berolahraga dengan karakteristik cepat dan intensitas tinggi melalui simulasi pertandingan. (Mohr et al., 2016). Pelatih perlu mengetahui tujuan latihan dan karakteristik yang sesuai dengan fisiologis cabang olahraga. Perlu adanya peran pelatih untuk meningkatkan kemampuan anaerobik. (Sørensen et al., 2014). Kapasitas Anaerobik adalah proses pemenuhan energi dalam tubuh memandaatkan glikogen untuk dijadikan energi. Pada sistem glikolisis anaerobik, glikogen yang ada dalam otot dipecah menjadi glukosa untuk memperoleh energi. (Suharjana, 2013).

Layaknya cabang olahraga lain, dalam mengukur kemampuan teknik dasar pemain futsal harusnya memiliki instrument tes yang spesifik dan mengikuti perkembangan teknologi sehingga hasil yang didapatkan lebih akurat. Namun setelah peneliti melakukan observasi terkait instrument tes keterampilan dalam bermain futsal, kebanyakan pengembangan tes keterampilan dalam bermain futsal dikembangkan dalam bentuk rangkaian. Jadi tidak spesifik mengukur satu keterampilan saja. Untuk tes dribbling dalam permainan futsal sendiri ada yang telah dikembangkan, namun masih dilakukan secara manual. Bentuk tes dribbling futsal tersebut masih mengikuti model dalam tes dribbling sepakbola.

Hasil diskusi dengan beberapa orang pelatih dan pelaku olahraga futsal bahwa mereka sangat membutuhkan instrumen tes dribbling pada olahraga futsal karena sampai saat ini untuk mengukur hasil kemampuan dribbling pada olahraga futsal masih berpedoman kepada instrumen tes dribbling pada permainan sepakbola. Walaupun secara keseluruhan tekhnik dribbling pada permainan sepakbola dan futsal sama, namun penggunaan bola dan lapangan yang berbeda tentu akan berdampak pada ketepatan hasil pengukuran ketika pelaksanaan tes. Ukuran bola pada permainan futsal lebih kecil dan lebih berat dibandingkan dengan bola pada permainan sepakbola. Lapangan futsal juga memiliki ukuran yang lebih kecil dibandingkan dengan lapangan sepakbola, serta permukaan lapangannya pun juga berbeda.

Melihat kebutuhan terkait instrument yang lebih spesifik tersebut, maka peneliti ingin mengembangkan instrumen tes dribbling pada olahraga futsal dengan teknologi mikrokontroler untuk mempermudah pelatih menilai kemampuan dribbling para pemainnya. Teknologi mikrokontroler nantinya dapat membantu dalam mendapatkan data yang akurat terkait kemampuan dribbling pemain dalam permainan futsal.

Suparno (2015: 4), mengatakan bahwa teknik mendasar yang wajib dimiliki pemain futsal yaitu dribbling, shooting dan passing. Salah satu kemampuan teknik yang penting dan harus dikuasai oleh setiap pemain futsal adalah teknik dribbling. Lhaksana, (2011: 33) menyatakan dribbling merupakan teknik yang dimiliki pemain dalam menguasai bola sebelum diberikan kepada rekan satu timnya untuk menciptakan peluang dalam mencetak gol. Jaya, (2008) menyatakan bahwa dribbling merupakan tendangan bola terputus-putus atau pelan-pelan.

Dalam peningkatan kemampuan dribbling seorang pemain, hasil tes dan pengukuran menjadi tolak ukur yang sangat penting untuk menetapkan program latihan yang akan diberikan. Untuk memperoleh data terkait baik atau tidaknya kemampuan dribbling seorang pemain tersebut tentu dibutuhkan instrument tes yang valid dan reliabel untuk mengukurnya. Menurut Winarno (2013:96), "Instrumen penelitian itu adalah alat-alat yang digunakan untuk memperoleh atau mengumpulkan data 
dalam rangka memecahkan masalah penelitian atau mencapai tujuan penelitian". Jika informasi yang didapat tidak tepat, pilihan yang diambil menjadi salah. Djaali dalam (Sahri, 2020) menyatakan Instrumen tes atau estimasi adalah sah jika dapat mengukur apa yang seharusnya diukur. Selanjutnya Sumadi S dalam (Sahri, 2020) menyatakan dalam penelitian, aparatus atau instrumen pemilahan informasi menentukan sifat informasi yang dikumpulkan dan sifat informasi menentukan kualitas penelitian.

Salah satu hasil penelitian pengembangan yang dilakukan untuk mengembangkan instrument tes dribbling futsal adalah penelitian yang dilakukan oleh (Dewi \& Pakpahan, 2018), dimana dihasilkan instrument tes dribbling dengan design sebagai berikut:

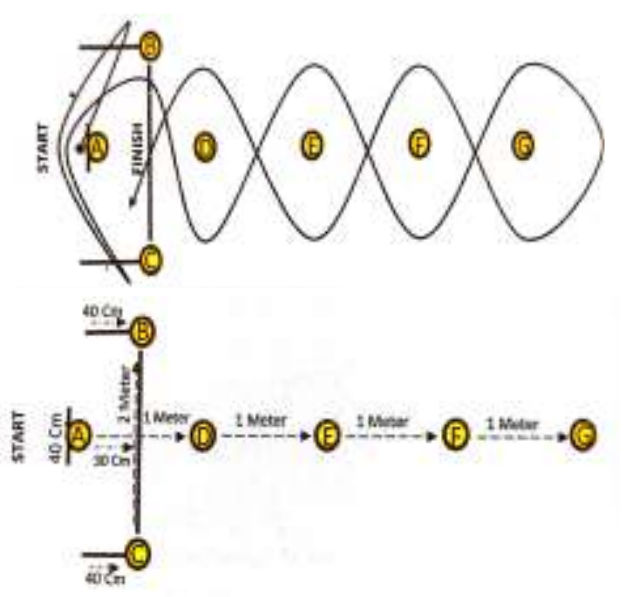

Gambar 1. Design instrumen Tes Dribbling Futsal

Tabel 1. Norma Kecepatan Dribbling

\begin{tabular}{cc}
\hline Kategori & Waktu (Detik) \\
\hline Baik Sekali & $<11,91$ \\
Baik & $11,91-13,20$ \\
Sedang & $13,21-14,50$ \\
Kurang & $14,51-15,80$ \\
Kurang Sekali & $>15,80$ \\
\hline
\end{tabular}

Dalam petunjuk pelaksanaanya, Testee berdiri dibelakang cone pertama dan mulai melakukan dribbling diluar cone 1,2,3. Setelah itu dribbling zigzag melewati cone 4, 5, 6, 7. Kemudian diteruskan dribbling zigzag dari cone 7, 6, 5, 4. Setelah melewati cone 4, maka waktu dihentikan. Testee melakukan dribbling sebanyak tiga kali percobaan.

Adapun penilaian acuan patokan diatas menggunakan penilian acuan patokan skala lima, Menurut (Sriyanto, 2019), Penilaian Acuan Patokan berarti bahwa nilai yang akan diberikan kepada siswa didasarkan pada standar mutlak atau kriteria yang telah ditetapkan. Dengan demikian pada Penilaian Acuan Patokan nilai yang diberikan kepada objek ukur menunjukkan tingkat penguasaan terhadap kriterion yang telah ditentukan

Dalam pelaksanaan tes dengan intrumen yang telah dikembangkan pada penelitian tersebut masih dilakukan secara manual, yaitu memanfaatkan kemampuan manusia dalam mendata kecepatan dribbling pemain menggunakan stopwatch serta pencatatan hasil. Berdasarkan fakta yang ada, maka munculah pemikiran untuk mengembangkan instrumen tes dribbling yang telah ada dan kemudian ditambahkan dengan teknologi berbasis digital sebagai media pengukuran. Tujuannya adalah untuk memberikan alat uji dribbling yang dapat mengukur kecepatan dribbling yang disesuaikan dengan kebutuhan pemain futsal. Selain itu, instrumen yang dibuat dapat mempertimbangkan kemahiran dan kecukupan penyajian perangkat sehingga sangat baik dapat digunakan kapanpun dan dimanapun. Perangkat yang 
direncanakan bersifat dinamis (dumping framework) sehingga sangat mudah digunakan. Dengan rencana instrumen berbasis canggih, diharapkan memiliki kemampuan untuk membatasi kesalahan manusia dalam berbagai informasi, sehingga informasi yang diperoleh benar-benar substansial dan dapat diandalkan. Menurut (Arsil, 2017), "tes dribbling adalah tes dengan menggiring bola secepat mungkin melewati semua rintangan yang telah ditentukan".

\section{METODE}

Metode dalam penelitian ini menggunakan metode Research and Development (R\&D). Sukmadinata, (2016) menjelaskan bahwa research and development adalah interaksi atau langkahlangkah untuk menumbuhkan item lain atau bekerja pada item saat ini, yang dapat direpresentasikan. Menurut (Zainal, 2014)," research and development adalah strategi yang dapat digunakan untuk mengatasi lubang antara eksplorasi esensial dan pengujian terapan"

Tahapan atau langkah-langkah penelitian dan pengembangan dalam penelitian ini sebagai berikut; 1) kapasitas persoalan, 2) pengambilan data, 3) disain alat, 4) validasi disain, 5) revisi desain, 6) uji coba produk, 7) revisi produk, 8) percobaan pemakaian, 9) revisi produk dan 10) perbanyak pembuatan produk (Borg and Gall dalam Sugiyono, 2013:409). Namun pada Penelitian yang akan mengembangkan instrumen tes dribbling futsal menggunakan teknologi mikrokontroler arduino ini hanya sampai pada tahap kesembilan, karena keterbatasan yang dimiliki peneliti.

Penelitian ini dilakukan di Lapangan Ardi Futsal dan Lapangan Analis Futsal, Kecamatan Sijunjung, Kabupaten Sijunjung. Waktu penelitian ini dilakukan pada tanggal pada bulan Maret dan April 2021. Populasi pada penelitian ini adalah seluruh siswa SMA Negeri se Kecamatan Sijunjung, yaitu SMA N 1, SMA N 2 dan SMA N 9 Sijunjung. Teknik yang digunakan dalam pengambilan sampel adalah teknik purposive sampling. Sampel untuk uji coba kelompok kecil adalah 15 orang siswa putra, dan ujicoba kelompok besar adalah 45 siswa. Jadi secara keseluruhan sampel dalam penelitian ini adalah sebanyak 60 orang.

\section{HASIL DAN PEMBAHASAN}

\section{Hasil}

Dari hasil penelitian yang dilakukan, alat atau instrument tes dribbling dengan menggunakan teknologi mikrokontroler arduino yang telah dibuat, kemudian divalidasi oleh tiga orang ahli melalui angket yang telah disediakan. Tiga orang ahli sebagai validator tersebut adalah ahli evaluasi, tes dan pengukuran, ahli futsal dan ahli IT. Dari hasil validasi oleh tiga orang ahli tersebut jika di rata-ratakan maka diperoleh persentase hasil validasi sebesar 91,33\% dan dapat disimpulkan bahwa alat hasil pengembangan instrument tes dribbling futsal menggunakan teknologi mikrokontroler arduino "Sangat Baik/Layak".

Untuk praktisitas didapat hasil sebesar 94\% dan dapat disimpulkan bahwa alat hasil pengembangan instrument tes dribbling futsal menggunakan teknologi mikrokontroler arduino memiliki tingkat praktisitas "Sangat Baik/Layak". Kemudian untuk efektivitas didapat hasil sebesar $90 \%$ dan dapat disimpulkan bahwa alat hasil pengembangan instrument tes dribbling futsal menggunakan teknologi mikrokontroler arduino memiliki efektivitas "Sangat Baik/Layak". Uji validitas dilakukan untuk menentukan apakah instrument tes yang dikembangkan layak atau tidak digunakan dalam tes dribbling futsal. (Sukardi, 2015) menyatakan bahwa "Validitas suatu instrument penelitian, tidak lain adalah derajat yang menunjukan dimana suatu tes mengukur apa yang hendak diukur".

Kemudian uji reliabilitas pada uji coba kelompok kecil didapatkan nilai $r$ sebesar 0.986 dengan kategori "Tinggi" dan pada uji coba kelompok besar didapatkan nilai $r$ sebesar 0.947 dengan kategori "Tinggi" sehingga dikatakan tingkat reliabilitas alat yang dilakukan pada uji coba kelompok besar dan kelompok kecil memiliki kategori reliabilitas "Tinggi". Maka dapat disimpulkan instrument yang dikembangkan sebagai instrument tes dribbling pemain futsal berbasis digital dikatakan reliable dan konsisten dalam mengambil data dribbling pemain futsal.

Uji releabilitas dilakukan untuk melihat konsistensi hasil pengukuran. Ali (2012:117) mengemukakan bahwa reliabilitas merujuk pada sejauh mana alat ukur dan hasil pengukuran relatif 


\section{Jurnal Keolahragaan 9 (2), 2021 - 260}

Randy Febri Tauba, Bafirman HB

konsisten jika pengukuran dilakukan berulang-ulang. Reliabilitas didapatkan dengan menghitung nilai korelasional uji coba kelompok kecil dan uji coba kelompok besar dengan metode Test and Retest. Instrument tes dribbling yang telah dibuat adalah sebagai berikut:

\section{Sensor}

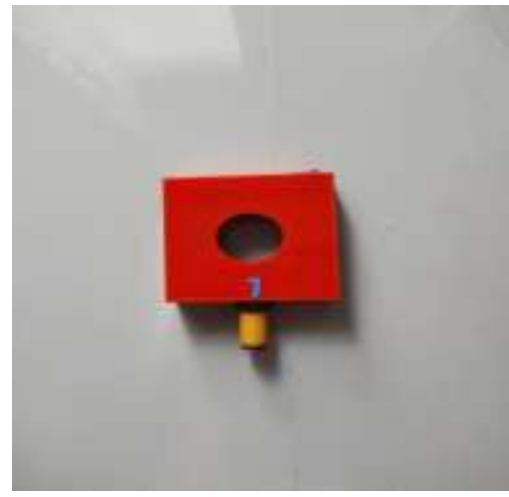

Gambar 2. Sensor

Sensor adalah alat yang dipasang pada cone untuk mendeteksi gerakan dribbling pemain. Sensor dipasang pada cone dan disusun dengan design yang telah ditentukan.

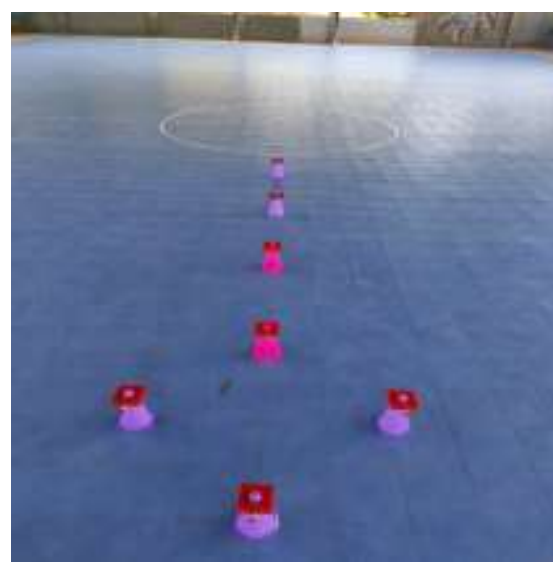

Gambar 3. Sensor terpasang pada cone

2. Receiver

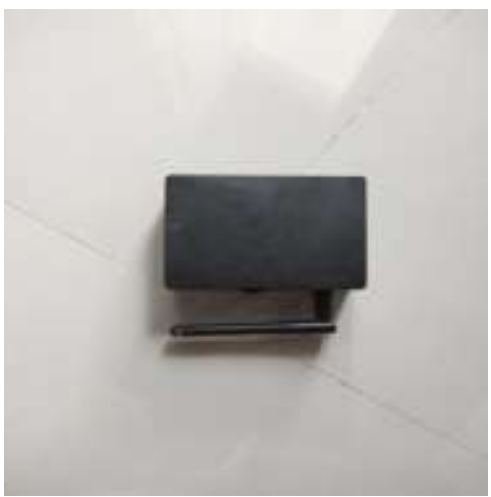

Gambar 4. Receiver

Receiver berfungsi sebagai penerima data dari sensor dan meneruskan data tersebut ke aplikasi dribbling test pada android.

3. Aplikasi Dibbling Test

Copyright $@$ 2021, Jurnal Keolahragaan, ISSN 2339-0662 (print), ISSN 2461-0259 (online) 


\section{Jurnal Keolahragaan 9 (2), 2021 - 261}

Randy Febri Tauba, Bafirman HB

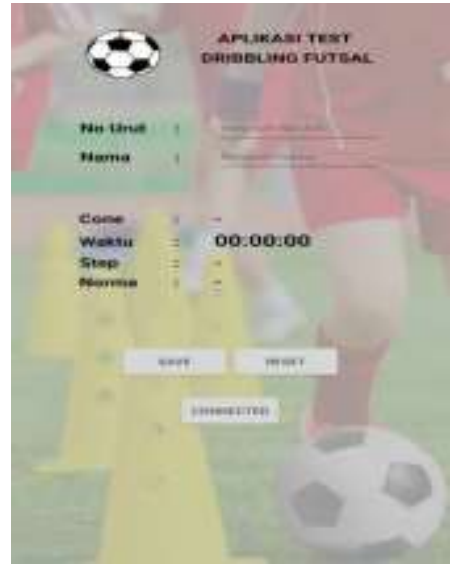

Gambar 5. Tampilan aplikasi dribbling

Aplikasi dribbling test adalah aplikasi yang menampilkan proses pelaksanaan test dribbling. Hasil dari tes dribbling lansung tersimpan ke dalam Google spreadsheet sehingga bisa dilihat waktu dan norma yang didapatkan oleh testee. Bagi para software engineer untuk menuju ke antarmuka pemrograman aplikasi (programming interface) di android membutuhkan product improvement pack (SDK) yang diberikan oleh Android, SDK ini memberikan pendekatan untuk menuju ke antarmuka pemrograman aplikasi di Android. (Rolly \& Hakiem, 2015).

Kemudian untuk prosedur penggunaan instrument adalah sebagai berikut:

A. Tahap Menghubungkan Android dengan Alat Test Dribbling

1) Hidupkan alat penerima sinyal Test Dribbling.

2) Hidupkan Bluetooth android.

3) Cari nama Bluetooth JDY-31-SPP (atau pada list pertama pada Bluetooth yang muncul)

4) Pilih dan hubungkan dengan perangkat Android (gunakan password 1234 atau 0000).

5) Tunggu hingga proses pairing berhasil.

B. Pemakaian Aplikasi Dribbling

1) Hidupkan sensor alat test dribbling dan pasangkan pada cone.

2) Atur posisi cone dengan jarak yang sudah ditentukan.

3) Hidupkan Bluetooth android dan buka aplikasi dribbling.

4) Tekan tombol CONNECT.

5) Pilih nama Bluetooth JDY-31-SPP. Apabila android dan alat sudah terhubung, maka akan muncul kata CONNECTED.

6) Input nama dan no peserta pada kolom yang tersedia jika diperlukan.

7) Pada tahap ini peserta sudah dapat melakukan test dribbling, waktu dimulai secara otomatis apabila peserta melewati cone-1

8) Peserta diharuskan melewati cone sesuai nomor urut. Apabila peserta tidak melewati cone sesuai nomor urut maka data peserta tidak terbaca.

9) Waktu test dribbling dapat berhenti otomatis apabila peserta sudah melewati cone-4 setelah terlebih dahulu melewati cone 7 .

10) Tester diberi kesempatan 3 kali percobaan seandainya terjadi kesalahan.

11) Setelah melakukan percobaan yang benar, maka dapat muncul waktu dan norma pada aplikasi android.

12) Tekan tombol SAVE untuk menyimpan data, maka data otomatis tersimpan pada google spreadsheet.

13) Tekan tombol RESET untuk mengulangi proses pengambilan data

C. Pendataan hasil tes

1. Buka file google spreadsheet pada drive

2. Lihat data sesuai dengan nama yang telah dituliskan ketika pelaksanaan tes pada android

3. Sesuaikan juga dengan waktu pelaksanaan 
Instrument tes dribbling yang dilaksanakan secara manual tentu sangat berbeda jika dibandingkan dengan yang berbasis digital. Perbedaan tersebut diuraikan sebagai berikut: (1) Segi pelaksanaan, dimana antara tes manual dengan tes yang berbasis digital sama, karena dalam penelitian ini memang mengembangkan design yang telah ada dengan ditambahkan teknologi berbasis digital mikrokontroler arduino, serta pemanfaatan aplikasi android dan google spreadsheet. Keunggulannya adalah lebih praktis dalam pelaksanaan. (2) Segi pencatatan hasil. Pada pelaksanaan tes manual masih menggunakan stopwatch untuk menghitung waktu kecepatan dribbling dan dikontrol oleh manusia. Pada penelitian ini diubah menggunakan sensor yang secara otomatis mencatat waktu pelaksanaan yang kemudian ditampilkan dalam bentuk aplikasi android dan juga hasil data tersebut bisa lansung tersimpan pada google spreadsheet. (3) Segi human error. Pada pelaksanaan tes manual, persentase kemungkinan terjadinya kesalahan manusia masih besar seperti keterlambatan dalam menghidupkan stopwatch, kemudian kekeliruan ketika pencatatan waktu pada lembar hasil yang telah disediakan. Sedangkan pada tes digital, persentase kemungkinan terjadinya kesalahan manusia bisa diminimalisir, karena data tes lansung tampil pada aplikasi android dan setelah selesai dapat bisa lansung disimpan ke dalam google spreadsheet. (4) Segi keefektifan dan keefisienan. Pada pelaksanaan tes manual, petugas harus menghitung dan mencatat hasil tes secara manual kecepatan dribbling yang telah dilakukan oleh testee. Sedangkan pada pelaksanaan tes berbasis digital, petugas hanya menyimpan data hasil kecepatan dribbling. Data tersebut lansung tersimpan ke dalam google spreadsheet, yang nantinya bisa didownload dalam bentuk tabel Microsoft excel.

Dilihat dari perbedaan antara tes manual dengan tes dengan berbasis digital bisa diartikan bahwa kemampuan instrument tes digital lebih baik dan lebih efisien dalam mengukur kecepatan dribbling pemain, sehingga tujuan pelaksanaan tes dapat tercapai.

Tes keterampilan olahraga berguna untuk mengukur penguasaan atau keterampilan seseorang dalam bermain salah satu cabang olahraga melalui pengukuran teknik-teknik dasar permainan (Dian, 2014 : 5). Begitu juga dengan olahraga futsal, tes bisa berfungsi sebagai tolak ukur seorang pelatih dalam menentukan kemampuan pemain atau atlet. Tes berfungsi sebagai alat pengukur peserta latihan dan keberhasilan program latihan (Sudijono, $2011: 67$ ).

Tes berfungsi sebagai alat untuk memperkirakan tingkat perbaikan atau kemajuan yang telah dicapai pemain selama proses latihan maupun pembinaan. Sedangkan tes sebagai alat pengukur keberhasilan program latihan berarti melalui tes akan diketahui seberapa jauh program latihan dapat tercapai. Data hasil tes bisa digunakan untuk menetapkan program latihan yang diberikan, atau menjadi pedoman dalam rangka seleksi pemain. Pada permainan futsal tentu juga dibutuhkan instrument tes untuk melihat kemampuan pemain.

Instrument tes tersebut tentu menyangkut empat komponen, yaitu fisik, teknik, taktik dan mental. Menurut (Riyadi, 2013), "Futsal adalah aktivitas permainan dua beregu dengan jumlah pemain lima lawan lima dengan permainan yang sangat cepat dan peraturan yang sudah ditentukan dengan tujuan untuk mencetak gol ke gawang lawannya". Dilihat dari tujuan permainan, permainan futsal memiliki banyak kesamaan dengan permainan sepakbola. Namun yang membedakan terletak pada ukuran lapangan, ukuran bola, jumlah pemain, kemudian beberapa aturan yang yang lebih spesifik dan menyesuaikan. Untuk peraturan dibuat agak lebih ketat pada permainan futsal, jadi game ini berjalan dengan permainan yang wajar dan lebih jauh lagi untuk menghindari luka yang bisa terjadi. Menurut (Halim, 2012), perbedaan antara futsal dan sepakbola adalah sebagai berikut :

Tabel 2. Perbedaan Futsal dan Sepakbola

\begin{tabular}{ll}
\hline \multicolumn{1}{c}{ Futsal } & \multicolumn{1}{c}{ Sepakbola } \\
\hline Terdiri dari 5 orang pemain & Terdiri dari 11 orang pemain \\
Pertukaran pemain tidak dibatasi & Pertukaran pemain terbatas \\
Sepakan boal ke dalam & Lemparan bola ke dalam \\
& Stopped clock (dioperasikan oleh pencatat \\
Waktu berjalan (running clock) & waktu) \\
$2 \times 20$ menit & $2 \times 45$ menit \\
Tidak berlaku aturan offside & Berlaku aturan offside
\end{tabular}


Jurnal Keolahragaan 9 (2), 2021 - 263

Randy Febri Tauba, Bafirman HB

\begin{tabular}{lc}
\hline \multicolumn{1}{c}{ Futsal } & Sepakbola \\
\hline $\begin{array}{l}\text { Pemain yang dikartu merah bisa diganti oleh } \\
\text { pemain lain setelah 2 menit atau terciptanya gol } \\
\text { oleh lawan }\end{array}$ & Pemain yang dikartu merah tidak bisa diganti \\
\hline
\end{tabular}

Disamping perbedaan diatas, yang menjadi persamaan dan sangat penting adalah kesamaan dalam empat momen dalam permainan. Keempat momen tersebut adalah menyerang (attack), transisi menyerang ke bertahan (transition attack to defense), bertahan (defense), transisi bertahan ke menyerang (transition defense to attack). Semua komponen, baik fisik, teknik, taktik maupun mental sangat diperlukan dalam ke empat momen tersebut.

Dalam usaha menguasai keempat momen tersebut maka dibutuhkan keterampilan yang baik dari seorang pemain. Wimala (2019: 347) menyatakan bahwa "The performance of the futsal game is very much supported by the skills possessed by the players". Dari pernyataan tersebut dapat disimpulkan bahwa keterampilan sangat dibutuhkan dalam performa permainan futsal. Salah satu komponen keterampilan dalam permainan futsal yaitu dribbling. Dribbling lebih dominan dilaksanakan dalam momen menyerang dengan tujuan melewati lawan dan merusak pertahana lawan. Menurut Ikhsan (2019: 15), "Dribbling adalah keterampilan dasar dimana pemain melakukan gerakan berlari sambil mendorong bola menggunakan kaki sehingga adanya perpindahan bola dari suatu daerah ke daerah yang lain atau membuka daerah pertahanan lawan". Tujuan dari dribbling adalah untuk menghindari lawan, mengarahkan bola ke ruang kosong, melarikan diri dari kendali lawan, membuka ruang untuk rekan, dan membuka pintu untuk mengambil tembakan ke gawang. Pemain yang bisa melakukan dribbling dengan baik mampu menarik pemain bertahan lebih banyak, sehingga bisa memberikan ruang kosong yang lebih banyak kepada pemain lain untuk mendapatkan peluang mencetak gol.

\section{Pembahasan}

Firmansah, (2019) futsal merupakan permainan yang dimainkan oleh dua kelompok yang dimainkan oleh satu kelompok yang terdiri dari lima pemain, kedua kelompok bermain untuk menempatkan bola ke gawang, dan mengumpulkan tujuan sebanyak apa pun yang bijaksana untuk keluar sebagai pemenang. Sementara itu menurut Lhaksana dalam (Gunawan, 2016) Futsal sebenarnya merupakan olahraga yang kompleks, karena membutuhkan strategi dan strategi yang luar biasa. Demikian pula, sejauh ini, permainan futsal unik dalam kaitannya dengan permainan yang berbeda. Atribut olahraga futsal membutuhkan ketekunan, kecepatan, ketekunan, kekuatan, dan ketangkasan dalam jangka waktu yang cukup signifikan.

Penelitian ini didasari oleh realita yang ada dilapangan, dimana belum adanya alat ukur yang mampu mengukur kecepatan dribbling pemain futsal dengan menggunakan teknologi digital. Apabila dikaitkan dengan tugas dan tanggung jawab seorang pelatih, kemudian, pada saat itu setiap pelatih harus memiliki informasi tentang setiap komponen yang diperlukan dalam permainan yang dia siapkan. Febriansyah Afdol, (2018) menyatakan pelatih adalah seseorang yang mempunyai kemampuan dan pengetahuan tentang cara-cara melatih atau mengembangkan kemampuan dan keterampilan seseorang atau lebih. Untuk melatih dan mengembangkan kemampuan seorang atlit maka akan lebih mudah apabila didukung teknologi keolahragaan. Untuk mengumpulkan informasi yang substansial, diperlukan instrumen yang memiliki tingkat kepastian dan kepercayaan yang telah dicoba secara tentatif. Ketepatan dalam pemilihan instrumen merupakan salah satu komponen penting yang harus diperhatikan oleh pelatih dalam memulihkan data pemain. Begitu juga dengan futsal, dimana seorang pelatih yang profesional tentu butuh seluruh data terkait keterampilan atau kemampuan pemainnya dalam bermain.

Teknik merupakan salah satu ketrampilan yang harus dimiliki oleh setiap pemain, permainan futsal akan lebih menarik apabila setiap pemain memiliki penguasaan teknik yang baik, sehinggan mutu permainan akan tercapai (Corrêa et al., 2020). Ada beberapa teknik dalam permainan futsal yang harus dikuasai oleh pemain futsal, yaitu passing, control, dribbling, dan shooting (Festiawan, 2020). Salah satu keterampilan pada permainan futsal yang sangat penting adalah dribbling (Siswandi, 2018a), Untuk tampil baik dalam permainan futsal, seorang pemain harus memiliki pilihan untuk menumpahkan yang hebat. Dribbling dalam permainan futsal mempunyai fungsi yang sangat penting dalam proses penyerangan dalam permainan futsal. Teknik dribbling yang sangat baik dari seorang pemain mampu menyedot seluruh pertahanan dari tim lawan. Hal tersebut tentu dapat membuka ruang yang kosong

Copyright @ 2021, Jurnal Keolahragaan, ISSN 2339-0662 (print), ISSN 2461-0259 (online) 
untuk pemain lain dalam usaha mencetak gol ke gawang lawan. Dengan demikian dribbling berfungsi sebagai perusak pertahanan tim lawan. keterampilan dribbling yang baik setiap pemain dalam suatu tim, akan meningkatkan peluang kemenangan yang lebih besar dalam suatu pertandingan.

Untuk memperoleh data terkait baik atau tidaknya kemampuan dribbling seorang pemain tentu dibutuhkan instrument tes yang valid dan reliable untuk mengukurnya. Djaali dalam Januar Sahri (2020; 2) menyatakan bahwa instrumen tes atau estimasi adalah sah jika dapat mengukur apa yang seharusnya diukur. Selain itu, Sumadi S dalam (Sahri, 2020) mengungkapkan bahwa dalam suatu penelitian, perangkat atau instrumen pemilah informasi menentukan sifat informasi yang dikumpulkan dan sifat informasi menentukan sifat eksplorasi.

Dribbling adalah kemampuan yang dimiliki setiap pemain dalam mengontrol bola sebelum diberikan kepada temannya untuk membuat peluang untuk mencetak gol. (Siswandi, 2018). Sedangkan Rochman, (2016) mengatakan bahwa dribbling adalah kemampuan yang dimiliki setiap pemain dalam mengontrol bola sebelum diberikan kepada temannya untuk membuat peluang untuk mencetak gol. Hal yang penting untuk diketahui dalam strategi spilling, khususnya: mengontrol bola dan menjauh dari lawan, menjaga keseimbangan tubuh saat melakukan dribbling, memusatkan mata setiap kali menyentuh bola, menyentuh bola harus memanfaatkan bagian bawah kaki tanpa henti.

Seiring berkembangnya teknologi, Di dunia olahraga sudah banyak teknologi yang di kembangkan untuk meningkatkan prestasi altet seperti penelitian yang dilakukan (Syakur \& Paramitha, 2017) membuat alat pelontar bola futsal berbasis mikrokontroler alat ini menggunakan software pemograman Arduino. Selain itu ada juga penelitian dari (Rahmat, Rusdiana, \& Supriyatna, 2016) yang membuat Alat ukur kecepatan lari berbasis microkontroler dengan interfacing personal computer. Kemudian penelitian (Jaenudin, 2018) yang membuat alat media latihan passing berbasis arduino uno dalam cabang olahraga futsal.

Pada penelitian berikut dikembangkan instrument tes dribbling futsal yang menggunakan teknologi mikrokontroler arduino dengan pemanfaatan aplikasi android sebagain tampilan dan pencatatan data. Penelitian ini merupakan penelitian yang dikembangkan dari hasil penelitian terdahulu terkait dengan instrument tes dribling futsal. Namun design instrument tes dribbling futsal tersebut belum menggunakan teknologi dan diaplikasikan dalam bentuk tampilan pada android. Pada penelitian tersebut masih dilakukan secara manual, yaitu memanfaatkan kemampuan manusia dalam mendata kecepatan dribbling pemain menggunakan stopwatch. Sebanding dengan pemanfaatan instrumentasi sebagai alat penduga, alat yang digunakan dalam pendugaan kecepatan spilling futsal ini cocok dengan penelitian sebelumnya adalah menggunakan instrument tes dribbling bola melewati 7 buah cone yang telah ditentukan jaraknya. Dalam petunjuk pelaksanaanya, Testee berdiri dibelakang cone pertama dan mulai melakukan dribbling diluar cone 1, 2, 3. Setelah itu dribbling zigzag melewati cone 4, 5, 6, 7. Kemudian diteruskan dribbling zigzag dari cone 7, 6, 5, 4. Setelah melewati cone 4, maka waktu dihentikan. Testee melakukan dribbling sebanyak tiga kali percobaan. Data waktu yang didapat lansung dicatat ke lembar yang telah disediakan Data yang diambil adalah waktu terbaik dari tiga kali percobaan tersebut.

Berdasarkan realita yang ada, maka munculah pemikiran-pemikiran untuk membuat serta mengembangkan instrumen tes dribbling yang berbasis teknologi digital sebagai media pengukuran. Tujuannya adalah untuk memberikan alat uji tumpahan yang dapat mengukur kecepatan tumpahan yang disesuaikan dengan kebutuhan pemain futsal. Selain itu, instrumen yang dibuat mempertimbangkan produktivitas dan kecukupan penyajian perangkat sehingga dapat dimanfaatkan dengan baik kapan pun dan di mana pun. Perangkat yang direncanakan dimaksudkan untuk menjadi dinamis (kerangka dumping) sehingga sangat mudah digunakan. Dengan rancangan instrumen berbasis canggih, diharapkan memiliki kemampuan untuk membatasi kesalahan manusia dalam berbagai informasi, sehingga informasi yang didapat sangat penting dan dapat diandalkan.

Penelitian ini terfokus pada terciptanya alat ukur kecepatan dribbling pemain futsal berbasis digital menggunakan teknologi mikrikontroler ardunio. Design tes dribbling beserta norma untuk tes berbasis digital ini berdasarkan pada penelitian yang telah dilakukan sebelumnya. Produk yang akan dihasilkan dalam penenelitian ini adalah hasil pengembangan dari instrument tes dribbling futsal dengan penghitungan secara manual, kemudian di ubah menjadi berbasis teknologi dengan menggunakan sensor yang telah terhubung dengan teknologi wireless ke aplikasi android dan google spreadsheet. Pada saat pengambilan data pemain melakukan dribbling melawati cone yang telah ditentukan sesuai design yang 
ada dengan benar dan menghasilkan output data kecepatan dribbling pemain futsal. Kemudian hasil output data disimpan ke dalam google spreadsheet yang telah terhubung dengan aplikasi android. Data pada google spreadsheet bisa di download dengan tampilan Microsoft excel. Data hasil dribbling juga bisa lansung di cetak dengan printer. Tampilan hasil berupa waktu pelaksanaan dribbling, nomor urut testee, nama testee, kecepatan dribbling, dan norma yang sesuai dengan hasil kecepatan dribbling.

Pengambilan data dribbling futsal dilakukan di lapangan Ardi Futsal Sijunjung dengan sampel pemain futsal SMA N 9 Sijunjung yang berjenis kelamin laki-laki sebagai subjek uji kelompok kecil sebanyak 15 orang dan pada lapangan Analis Futsal Sijunjung dengan sampel pemain futsal SMA N 1 Sijunjung sebanyak 20 orang dan pemain futsal SMA N 2 Sijunjung sebanyak 25 Orang, sehingga total sebanyak 45 orang dengan jenis kelamin laki-laki untuk uji kelompok besar sebanyak 45 orang.

Instrument tes dribbling futsal divalidasi oleh tiga orang ahli melalui angket yang telah disediakan. Tiga orang ahli sebagai validator tersebut adalah ahli evaluasi, tes dan pengukuran, ahli futsal dan ahli IT. Dari hasil validasi oleh tiga orang ahli tersebut jika di rata-ratakan maka diperoleh persentase hasil validasi sebesar 91,33\% dan dapat disimpulkan bahwa alat hasil pengembangan instrument tes dribbling futsal menggunakan teknologi mikrokontroler arduino "Sangat Baik/Layak". Untuk praktisitas didapat hasil sebesar $94 \%$ dan dapat disimpulkan bahwa alat hasil pengembangan instrument tes dribbling futsal menggunakan teknologi mikrokontroler arduino memiliki tingkat praktisitas "Sangat Baik/Layak". Kemudian untuk efektivitas didapat hasil sebesar $90 \%$ dan dapat disimpulkan bahwa alat hasil pengembangan instrument tes dribbling futsal menggunakan teknologi mikrokontroler arduino memiliki efektivitas "Sangat Baik/Layak".

Kemudian uji reliabilitas pada uji coba kelompok kecil didapatkan nilai $\mathrm{r}$ sebesar 0.986 dengan kategori "Tinggi" dan pada uji coba kelompok besar didapatkan nilai r sebesar 0.947 dengan kategori "Tinggi" sehingga dikatakan tingkat reliabilitas alat yang dilakukan pada uji coba kelompok besar dan kelompok kecil memiliki kategori reliabilitas "Tinggi". Maka dapat disimpulkan instrument yang dikembangkan sebagai instrument tes dribbling pemain futsal berbasis digital dikatakan reliable dan konsisten dalam mengambil data dribbling pemain futsal.

Berdasarkan hasil uji validitas dan reliabilitas yang telah dilakukan diatas, maka dapat disimpulkan bahwa instrument tes dribbling futsal menggunakan teknologi mikrokontroler arduino layak digunakan untuk mengukur kecepatan dribbling pemain futsal.

Kelebihan instrument tes dribbling futsal menggunakan teknologi mikrokontroler arduino antara lain adalah sebagai berikut, a) Alat ini adalah alat yang mampu mengukur kecepatan dribbling futsal secara spesifik dengan menyesuaikan dengan kondisi pemain dilapangan, b) Alat mampu mengukur kecepatan dribbling futsal menggunakan sensor yang beroperasi secara terintegritas yang menghasilkan output data kecepatan dribbling futsal dan norma, c) Alat terbukti lebih efektif digunakan sebab proses pengukuran kecepatan dribbling dapat dilaksanakan lebih efektif dan efisien dengan tingkat ketelitian yang baik, d) Alat terbukti efisien dalam mendapatkan data kecepatan dribbling pemain futsal, e)Alat mampu mempermudah kerja pelatih dan pihak yang terkait dalam melaksanakan pengukuran, f) Bentuk dari alat menarik perhatian dari pada calon tester, g) Alat yang digunakan sangat modern dengan menggunakan sensor-sensor terkait, h) Output data lansung ditampilkan dalam bentuk aplikasi android, i) Data dari android akan tersimpan dalam google spreadsheet, j) Alat praktis dan mudah dibawa, k) Alat tidak menggunakan kabel, karena untuk konektivitas menggunakan teknologi wireless.

Kemudian ada pula kelahan alat, kelemahan instrument tes dribbling futsal menggunakan mikrokontroler arduino ini antara lain adalah sebagai berikut, a) Alat harus dioperasikan dengan menggunakan baterai, b) Tidak tahan air dimana alat tidak di desain water resist, c) Alat ini belum bisa mendeteksi gerakan yang benar dalam melakukan dribbling pada permainan futsal, dengan kata lain hanya untuk mengukur kecepatan dribbling saja.

\section{SIMPULAN}

Berdasarkan hasil pengolahan dan analisis data terhadap data hasil penelitian yang telah dilakukan, mengenai pengembangan instrument test dribbling futsal menggunakan teknologi mikrokontroler arduino diperoleh kesimpulan bahwa nama alat adalah Tauba Dribbling Test yang berfungsi sebagai instrumen pengukur kecepatan dribbling pada permainan futsal dengan tingkat validasi menurut para ahli rata-rata 91,33\% sehingga alat dapat dikatakan layak. Kemudian tingkat realibilitas hingga 0.986 pada uji coba kelompok kecil dan 0,947 pada uji coba kelompok besar, sehingga 
alat dikatakan reliabel dalam pengukuran kecepatan dribbling futsal. Alat memiliki beberapa keunggulan terutama dalam efektifitas penggunaan waktu dan spesifikasi tes khusus dribbling futsal, serta alat yang telah menggunakan teknologi wireless yang terhubung keaplikasi android.

\section{DAFTAR PUSTAKA}

Arsil. (2017). Evaluasi Pendidikan Jasmani dan Olahraga. UNP PRESS.

Castagna, C., D’Ottavio, S., ... J. V.-J. of S. and, \& 2009, U. (2009). Match demands of professional Futsal: $\quad$ a $\quad$ case study. https://www.sciencedirect.com/science/article/pii/S1440244008000686

Corrêa, U., Alberto, F., Clavijo, R., Letícia Da Silva, S., Corrêa, U. C., Augusto Costa De Oliveira, T., Letícia Da Silva, S., \& Zalla, S. (2020). Assessment of beginners' front-crawl stroke efficiency View project Adaptation in team sports View project International Journal of Performance Analysis in Sport Time of ball possession and visual search in the decision-making on shooting in the sport of futsal Time of ball possession and visual search in the decision-making on shooting in the sport of futsal. Article in International Journal of Performance Analysis in Sport. https://doi.org/10.1080/24748668.2020.1741916

Dewi, R., \& Pakpahan, M. T. (2018). PENGEMBANGAN INSTRUMEN TES DRIBBLING PADA OLAHRAGA FUTSAL. JURNAL PRESTASI, 2(3), 1-6. https://jurnal.unimed.ac.id/2012/index.php/jpsi/article/view/10124

Febriansyah Afdol, P. D. A. (2018). ANALISIS PELATIH FUTSAL DALAM MENJALANKAN COACHING PROCESS MURSYID EFFENDI FUTSAL AKADEMI U16 Afdol Febriansyah David Agus Prianto Abstrak. Jurnal Pendidikan Jasmani Dan Olahraga.

Festiawan, R. (2020). Pendekatan Teknik Dan Taktik: Pengaruhnya Terhadap Keterampilan Bermain Futsal. Jurnal Pendidikan Jasmani Dan Olahraga, 3(2), 143-155.

Firmansah, Y. (2019). Meningkatkan Keterampilan Dribbling Futsal melalui Metode Bermain. Ejournal.Bbg.Ac.Id, 6(1). https://ejournal.bbg.ac.id/penjaskesrek/article/view/841

Gunawan, Y. (2016). Hubungan Kecepatan Dan Kelincahan Terhadap Kemampuan Dribbling Bola Futsal Pada Atlet O2SN Kecamatan Sumedang Utara. Ejournal.Upi.Edu, 1. https://ejournal.upi.edu/index.php/SpoRTIVE/article/view/3413

Halim, S. (2012). 1 Hari Pintar Main Futsal. Media Pressindo.

Ishak, A., Lhaksana, \& Justin. (2008). Inspirasi dan Spirit Futsal. Raih asa sukses.

Jaenudin, J. dan A. R. (2018). Pengembangan media latihan passing berbasis arduino uno dalam cabang olahraga futsal. Researchgate.Net. https://doi.org/10.17509/jtikor.v3i1.9925

Jaya, A. (2008). Futsal Gaya Hidup, Peraturan, dan Tips-Tips Permainan. Pustaka timur.

Mohr, M., Draganidis, D., \& Chatzinikolaou, A. (2016). Muscle damage, inflammatory, immune and performance responses to three football games in 1 week in competitive male players. European Journal of Applied Physiology. https://doi.org/10.1007/s00421-015-3245-2

Riyadi, Nanang (2013). Tingkat Keterampilan Teknik Dasar Bermain Futsal Pemain Yang Menggunakan Lapangan Agung Futsal Arena Jatinom Klaten. Yogyakarta : UNY.

Rochman, R. (2016). PENGARUH LATIHAN BALL FEELING TERHADAP KETERAMPILAN DRIBBLING PADA PESERTA EKSTRAKURIKULER FUTSAL DI SMA NEGERI 5 KOTA. Eprints.Uny.Ac.Id. https://eprints.uny.ac.id/41301/1/skripsi_rudy saeful rochman_11601244168.pdf

Rolly, N., \& Hakiem, N. (2015). PENGEMBANGAN APLIKASI MOBILE ACADEMIC INFORMATION SYSTEM (AIS) BERBASIS ANDROID UNTUK PENGGUNA DOSEN DAN 
MAHASISWA (Studi Kasus : Pusat Teknologi Informasi dan Pangkalan Data (Pustipanda) UIN Syarif Hidayatullah Jakarta). JURNAL TEKNIK INFORMATIKA, 8(1). http://journal.uinjkt.ac.id/index.php/ti/article/view/1932

Sahri, J. (2020). Pengembangan Instrumen Tes Kelincahan Atlet Pencak Silat Berbasis Digital. Jurnal Keolahragaan. http://repository.unp.ac.id/26906/

Siswandi, E. (2018a). Pengaruh Metode Latihan Teknik Distribusi Terhadap Keterampilan Dribbling $\begin{array}{llll}\text { Zig-Zag Permainan } & \text { Futsal. }\end{array}$ https://ejournal.unib.ac.id/index.php/kinestetik/article/view/8739

Siswandi, E. (2018b). Pengaruh Metode Latihan Teknik Distribusi Terhadap Keterampilan Dribbling $\begin{array}{llll}\text { Zig-Zag Permainan } & \text { Futsal. } & \text { Ejournal.Unib.Ac.Id, } & 2018 \text { (2), }\end{array}$ https://ejournal.unib.ac.id/index.php/kinestetik/article/view/8739

Sørensen, C., Munday, P. L., \& Nilsson, G. E. (2014). Aerobic vs. anaerobic scope: Sibling species of fish indicate that temperature dependence of hypoxia tolerance can predict future survival. Global Change Biology, 20(3), 724-729. https://doi.org/10.1111/GCB.12399

Sriyanto, A. (2019). Teknik Pengolahan Hasil Penentuan Standar Asesmen, Teknik Pengolahan dengan Menggunakan Pendekatan Acuan (PAP) dan Acuan Norma (PAN). Teknik Pengolahan Hasil Penentuan Standar Asesmen, Teknik Pengolahan Dengan Menggunakan Pendekatan Acuan (PAP) Dan Acuan Norma (PAN), 5(No. 2), 242-258.

Suharjana. (2013). Perbedaan pengaruh hasil latihan peregangan statis dan dinamis terhadap kelentukan togok menurut jenis kelamin anak kelas 3 dan 4 sekolah dasar. Journal.Uny.Ac.Id. https://journal.uny.ac.id/index.php/jpji/article/view/3061

Sukardi. (2010). Evaluasi Pendidikan Prinsip \& Operasionalnya. Jakarta: PT Bumi Aksara

Sukmadinata. (2016). Metode Penelitian Pendidikan. Bandung: Remaja Rosda Karya

Zainal, A. (2014). Metode Pendidikan Metode dan Paradigma Baru. Rosda. 